(D) Canan Yılmaz,

(D) Ayşe Neslihan Balkaya,

(D) Filiz Ata,

(D) Halil Erkan Sayan,

(D) Ümran Karaca,

(D) Sami Yılmaz,

(D) Çağdaş Baytar

\section{Knowledge Level of Intensive Care Unit and Operating Room Employees During the Early Days of Coronavirus Disease-2019: A Cross-sectional Survey from Turkey}

\author{
Koronavirüs Hastalığı-2019'un Erken Döneminde \\ Yoğun Bakım Ünitesi ve Ameliyathane Çalışanlarının \\ Bilgi Düzeyi: Türkiye'den Kesitsel Anket
}

Received/Geliș Tarihi : 05.08.2020

Accepted/Kabul Tarihi : 25.10.2020

${ }^{\circ}$ Copyright 2021 by Turkish Society of Intensive Care Turkish Journal of Intensive Care published by Galenos Publishing House.

Canan Yılmaz, Ayșe Neslihan Balkaya, Filiz Ata, Halil Erkan Sayan, Ümran Karaca

University of Health Sciences Turkey, Bursa Yüksek Intisas Training and Research Hospital, Clinic of Anesthesiology and Reanimation, Bursa, Turkey

Sami Yılmaz

Retinagöz Private Eye Hospital, Clinic of Eye Surgery, Bursa, Turkey

Çağdaş Baytar

Bülent Ecevit University Faculty of Medicine,

Department of Anesthesiology and Reanimation,

Zonguldak, Turkey

Canan Yılmaz MD (凶),

University of Health Sciences Turkey, Bursa Yüksek

Ihtisas Training and Research Hospital, Clinic of

Anesthesiology and Reanimation, Bursa, Turkey

E-mail : dr_cnnylmz@yahoo.com

Phone : : +905059045989

ORCID ID : orcid.org/0000-0002-6626-3626
ABSTRACT Objective: Since the coronavirus is very infectious, preventive measures are at the forefront in the fight against coronavirus disease-2019 (COVID-19). High disease prevalence, rapid increase in the number of patients and high additional workload increase the risk of transmission for health care workers (HCWs). This study aimed to evaluate the knowledge level of intensive care unit (ICUs) and operating room (ORs) employees about COVID-19.

Materials and Methods: This study analysed questionnaires of $480 \mathrm{HCWs}$ in the ICU and/or OR. The participants completed a survey consisting of 29 questions that measured the level of knowledge of HCW on COVID-19 through manual methods or online.

Results: Our survey involved a total of $480 \mathrm{HCWs}$ who comprised nurses (38.2\%), doctors $(27.7 \%)$, anaesthesia technicians (18.1\%) and cleaning personnel (15.8\%). For the question "What are high-risk factors of COVID-19?" the respondents answered age 61-80 years (90.6\%), comorbidities (89.2\%) and being a HCW (85.6\%). On-the-job training on COVID-19 was given to only $46.9 \%$ of all participants. Moreover, $61.6 \%$ of the participants stated that they had hospital procedures on COVID-19. Social media (81.9\%) was the most common source of information. In addition, $74.8 \%$ of the participants were anxious about COVID-19, and $63.4 \%$ said that they wear a surgical mask only when they contact patients.

Conclusion: To ensure continuity in health care, HCWs, especially cleaning personnel who are often in contact with patients suspected with or patients with confirmed COVID-19, should use personal protective equipment, undergo on-the-job training programmes on the pandemic at regular intervals and be screened routinely.

Keywords: COVID-19, surveys and questionnaires, knowledge, health care, on-the-job training

ÖZ Amaç: Koronavirüs çok bulaşıcı olduğu için koronavirüs hastalığl-2019 (COVID-19) ile mücadelede önleyici tedbirler ön plandadır. Yüksek hastalık prevalansı, hasta sayısındaki hızlı artış ve artan ek iş yükü, sağlık çalışanlarına bulaşma riskini artıırı. Bu çalışmada, yoğun bakım ünitesi (YBÜ) ve ameliyathane çalışanlarının COVID-19 hakkındaki bilgi düzeylerini değerlendirmeyi amaçladık. Gereç ve Yöntem: Çalışmada YBÜ ve/veya ameliyathanede 480 gönüllü sağlık çalışanlarının cevapladığı sorular analiz edildi. Katılımcılar COVID-19'da sağlık çalışanlarının bilgi düzeyini ölçen, 29 sorudan oluşan anketi elle veya internet üzerinden tamamladılar.

Bulgular: Anketimize hemşire $(\% 38,2)$, doktor $(\% 27,7)$, anestezi teknisyeni $(\% 18,1)$ ve temizlik personeli $(\% 15,8)$ olmak üzere toplam 480 sağlık çalışanı katıldı. "Koronavirüsün bulaşma riskleri nelerdir?" sorusu: 61-80 yaş arasında olmak $(\% 90,6)$, ek hastalıklara sahip olmak $(\% 89,2)$ ve sağık çalışanı olmak $(\% 85,6)$ olarak yanıtlandı. Tüm katılımcıların sadece \%46,9'una COVID-19 hakkında kurum içi eğitim verildiği belirlenmiştir. Katılımcıların \%61,6'sı COVID-19'da hastane prosedürü olduğunu belirtmiştir. Sosyal medya $(\% 81,9)$ bilgi almanın en yaygın yoluydu. Katılımcıların \%74,8'i COVID-19 konusunda endişeliydi. Katılımcıların \%63,4'ü sadece hasta ile temas ettiklerinde cerrahi maske taktıklarını söylemiştir.

Sonuç: Sağlık hizmetlerinde sürekliliği sağlamak için, şüpheli/kesin COVID-19 ile temas halinde olan sağlık çalışanlarının özellikle de temizlik personellerinin kişisel koruyucu ekipmanları etkin bir şekilde kullanmaları, pandemi hakkında düzenli aralıklarla kurum içi eğitim programlarına katılmaları ve rutin olarak taranmaları gerektiğini düşünüyoruz.

Anahtar Kelimeler: COVID-19, anketler ve sorular, bilgi, sağlık hizmetleri, kurum içi eğitim 


\section{Introduction}

Coronaviruses (CoVs) are a family of viruses that can cause simple colds and more serious infections $(1,2)$. The World Health Organization (WHO) has declared coronavirus disease-2019 (COVID-19) infection as a pandemic because of increasing cases and mortality rates worldwide (3). In our country, the Ministry of Health has rapidly planned prevention and treatment protocols for COVID-19.

Hospitals, especially operating rooms (ORs) and intensive care units (ICUs), are areas with high contagious risk in terms of airway and patient contact. High disease prevalence, the rapid increase in the number of patients, and increased additional workload increase the risk of transmission for health care workers (HCWs). The fact that HCWs have insufficient awareness of COVID-19 prevention or have wrong information increases the risk of transmission (4). The literature reports that lack of information and misunderstandings among HCWs lead to delayed diagnosis, increased disease spread, and decreased infection control. Therefore, the levels of knowledge and education of HCWs play an important role in the effective control of pandemics $(5,6)$.

The primary purpose of this study was to evaluate the knowledge level of ICU and OR employees of COVID-19. The secondary aim was to raise awareness among HCWs and to assist health authorities in the prevention of occupational exposure in combating COVID-19.

\section{Materials and Methods}

This survey, which was approved by the Local Ethics Committee of the University of Health Sciences Turkey, Bursa Yüksek Ihtisas Training and Research Hospital (decision no: 2011-KAEK-25 2020/03-17, date: 18.03.2020), began on March 21, 2020, and was completed in 15 days. Four hundred eighty three volunteer HCWs in the ICU and/ or OR were included in the study. Those who had worked in the OR or ICU for less than 3 months and those who did not speak Turkish were excluded. A questionnaire consisting of 29 questions, measuring the level of knowledge of HCWs on COVID-19, was completed by the participants by hand or via the internet (https://docs.google.com/forms/d/1 Nk uykhg5XGsCL2oAWrVFGOWGATa6Rac1zv06Ou4YDXM/ edit). Informed consent forms were obtained before data collection by the researchers and were emailed to the participants of the study via the internet. Six questions of 29 are about demographic data and others are for measuring the level of knowledge of HCWs on COVID-19.

\section{Statistical Analysis}

Data was analyzed using the IBM SPSS 21 Windows (Statistical Package for the Social Sciences, Armonk, NY, USA) program. While categorical variables are expressed as number and percentage, differences between groups were analyzed with the chi-square test. The results were evaluated within the 95\% confidence interval and $p<0.05$ was considered significant. Post-hoc Tukey multiple comparison test was performed for comparisons of independent groups.

\section{Results}

Three questionnaires were not included in the study because they were completed less than $25 \%$. A total of 480 volunteer HCWs' questionnaires were analyzed statistically. Demographic data, methods for obtaining current information about COVID-19, and anxiety levels are given in Table 1. Only $46.9 \%$ of the respondents stated that they received training by their institutions and $61.6 \%$ stated that they had hospital procedures for COVID-19 (Table 1). The responses to the questions measuring the level of knowledge of the participants are given in Table 2. The most frequent answers in the questionnaire were droplets (93.1\%) for the question "What are COVID-19 transmission routes?", respiratory failure (97.7\%) for the question "What are the symptoms of COVID-19?", age 61-80 (90.6\%) for the question "Who are the high-risk groups?", for 14 days following contact $(63.9 \%)$ for the question "What is the time of infectiousness?", fever (96.9\%) for the question "What symptoms should be suspected in COVID-19?". 63.4\% of the participants preferred to wear a surgical mask only in contact with patients. "Endotracheal intubation should be performed by trained and experienced HCWs" was selected by $91.4 \%$ of participants.

According to professional titles, statistical analysis was done by dividing participants into five groups: Doctor (D), ICU nurse (IN), surgery nurse (SN), anesthesia technician (AT), and hospital cleaning personnel (CP). Group IN had significantly fewer years of work than group $D$, group $S N$, group AT $(p<0.001)$, and group CP $(p=0.006)$.

Wearing gloves was significantly less in group CP compared to group $D(p=0.004)$ and group AT ( $p=0.004)$. Using a face shield was significantly lower in group CP than group $D$, group AT, and group IN ( $p<0.001)$. The use of N95/97 


\begin{tabular}{|c|c|}
\hline Participation in the survey $(\mathrm{n}=480)$ & $n(\%)$ \\
\hline \multicolumn{2}{|l|}{ Gender } \\
\hline Female & $292(60.8)$ \\
\hline Male & 188 (39.2) \\
\hline \multicolumn{2}{|l|}{ Age } \\
\hline $21-30$ & $202(42.1)$ \\
\hline $31-40$ & 141 (29.4) \\
\hline $41-50$ & $110(22.9)$ \\
\hline $51-60$ & $24(5.0)$ \\
\hline$>60$ & $3(0.6)$ \\
\hline \multicolumn{2}{|l|}{ Working years } \\
\hline $1-5$ & 151 (31.9) \\
\hline $6-10$ & $111(23.5)$ \\
\hline $11-15$ & 78 (16.5) \\
\hline $16-20$ & $61(12.9)$ \\
\hline$>20$ & $72(15.2)$ \\
\hline \multicolumn{2}{|l|}{ Profession } \\
\hline Doctor & $133(27.7)$ \\
\hline Surgery nurse & 49 (10.2) \\
\hline ICU nurse & $135(28.1)$ \\
\hline Anesthesia technician & $87(18.1)$ \\
\hline Cleaning personnel & $76(15.8)$ \\
\hline \multicolumn{2}{|l|}{ Institution } \\
\hline University hospital & $29(6.0)$ \\
\hline Trainning and research hospital & $341(71.0)$ \\
\hline City/public hospital & $84(17.5)$ \\
\hline Private hospital & $26(5.4)$ \\
\hline \multicolumn{2}{|l|}{ Study unit } \\
\hline General ICU & $96(20.0)$ \\
\hline OR & $197(41.0)$ \\
\hline Together with general ICU and OR & $81(16.9)$ \\
\hline Other ICU & $106(21.1)$ \\
\hline On-the-job trainning & $225(46.9)$ \\
\hline Hospital procedure & $282(61.6)$ \\
\hline Presence of negative pressure in ICU & $211(48.0)$ \\
\hline Presence of negative pressure in OR & 165 (38.6) \\
\hline \multicolumn{2}{|l|}{ Ways to get updated information } \\
\hline Not following & $10(2.1)$ \\
\hline Social media & 393 (81.9) \\
\hline Newspaper & $86(17.9)$ \\
\hline Television & $375(78.1)$ \\
\hline Radio & 74 (15.4) \\
\hline People around & $150(31.3)$ \\
\hline Orginal articles & 140 (29.2) \\
\hline
\end{tabular}

\begin{tabular}{|c|c|}
\hline \multicolumn{2}{|l|}{ Table 1. Continued } \\
\hline Participation in the survey $(n=480)$ & n (\%) \\
\hline \multicolumn{2}{|l|}{ Anxiety level } \\
\hline None & $4(0.8)$ \\
\hline Mild & $117(24.4)$ \\
\hline Moderate & $177(36.9)$ \\
\hline Severe & $182(37.9)$ \\
\hline
\end{tabular}

Table 2. Questions and answers related to the level of knowledge

\begin{tabular}{|c|c|}
\hline Participation in the survey $(n=480)$ & Yes, n (\%) \\
\hline \multicolumn{2}{|c|}{ What are the transmission routes for COVID-19? } \\
\hline Droplet & $447(93.1)$ \\
\hline Respiratory & $387(80.6)$ \\
\hline Close contact & $392(81.7)$ \\
\hline Blood & $128(26.7)$ \\
\hline Body fluids & $236(49.2)$ \\
\hline Sexual contact & $131(27.3)$ \\
\hline \multicolumn{2}{|c|}{ What are the clinical conditions caused by COVID-19? } \\
\hline Simple colds & $272(56.7)$ \\
\hline Respiratory failure & $469(97.7)$ \\
\hline Kidney failure & $164(34.2)$ \\
\hline Liver failure & $106(22.1)$ \\
\hline Neurological failure & $102(21.3)$ \\
\hline Gastrointestinal system dysfunction & $126(26.3)$ \\
\hline \multicolumn{2}{|c|}{ Who are the high-risk groups in COVID-19? } \\
\hline Healthcare workers & $411(85.6)$ \\
\hline$<11$ age & $33(6.9)$ \\
\hline $11-20$ ages & $27(5.6)$ \\
\hline $21-40$ ages & $64(13.3)$ \\
\hline $41-60$ ages & $136(28.3)$ \\
\hline $61-80$ ages & $435(90.6)$ \\
\hline$>80$ age & $417(86.9)$ \\
\hline Comorbidities & $428(89.2)$ \\
\hline Being abroad & $390(81.3)$ \\
\hline Contact with a person who was abroad & $375(78.1)$ \\
\hline \multicolumn{2}{|l|}{ When is COVID-19 infectious? } \\
\hline One week previous & $163(34.2)$ \\
\hline 1-2 days previous & $130(27.3)$ \\
\hline For one week & $67(14.1)$ \\
\hline For 14 days & $304(63.9)$ \\
\hline For 1 month & $78(16.4)$ \\
\hline
\end{tabular}




\begin{tabular}{|c|c|}
\hline Participation in the survey $(n=480)$ & Yes, n (\%) \\
\hline \multicolumn{2}{|l|}{ How long does COVID-19 stay in the environment? } \\
\hline Does not survive & $23(4.8)$ \\
\hline A few minutes & $11(2.3)$ \\
\hline A few hours & $108(22.6)$ \\
\hline 1 day-1 week & $142(29.7)$ \\
\hline Unknown & $176(36.8)$ \\
\hline Variable according to the environment & $315(68.3)$ \\
\hline \multicolumn{2}{|c|}{ What are the suspected symptoms and conditions for COVID-19? } \\
\hline Cough & $446(92.9)$ \\
\hline Fever & $458(96.9)$ \\
\hline Weakness & $349(72.7)$ \\
\hline Respiratory distress & $452(94.2)$ \\
\hline Diarrhea & $203(42.3)$ \\
\hline Nausea/vomiting & 169 (35.2) \\
\hline Cannot be explained by any other clinical situation & $179(37.3)$ \\
\hline Being abroad & $426(88.8)$ \\
\hline Close contact with the patient & $424(88.3)$ \\
\hline Worsening of the clinical situation & $280(58.3)$ \\
\hline $\begin{array}{l}\text { Does the presence of another respiratory infection } \\
\text { eliminate the suspicion of COVID-19? }\end{array}$ & $39(8.1)$ \\
\hline \multicolumn{2}{|l|}{ Where is a COVID-19 sample taken from? } \\
\hline Mouth & $332(70.5)$ \\
\hline Nose & $329(69.9)$ \\
\hline Sputum & $252(53.5)$ \\
\hline Tracheal aspirates & $254(53.9)$ \\
\hline Bronchoalveolar lavage & $138(29.3)$ \\
\hline Blood & $173(36.7)$ \\
\hline Urine & $36(7.6)$ \\
\hline \multicolumn{2}{|l|}{ When should a surgical mask be worn in hospital? } \\
\hline All time & $164(34.2)$ \\
\hline In contact with patients & $305(63.4)$ \\
\hline Never & $12(2.5)$ \\
\hline Contionusly since the pandemic started & $123(25.6)$ \\
\hline \multicolumn{2}{|c|}{ Which should be used for PPE and disinfection for COVID-19? } \\
\hline Surgical mask & $241(50.2)$ \\
\hline Gloves & $456(95.0)$ \\
\hline Faceshield & $405(84.4)$ \\
\hline N95/99 mask & $440(91.7)$ \\
\hline Liquid soap & $290(60.4)$ \\
\hline Alcohol based hand disinfectant & $378(78.8)$ \\
\hline 1:10 dilution sodium hypochlorite & 140 (29.2) \\
\hline Apron & $414(86.3)$ \\
\hline
\end{tabular}

\begin{tabular}{|c|c|}
\hline $\begin{array}{l}\text { Should any preventive action be taken for a } \\
\text { person who has been in close contact with a } \\
\text { possible COVID-19 case? }\end{array}$ & $434(90.4)$ \\
\hline $\begin{array}{l}\text { Should people who are in close contact with a } \\
\text { definitive COVID-19 case be followed up at home } \\
\text { for } 14 \text { days? }\end{array}$ & $421(87.7)$ \\
\hline \multicolumn{2}{|l|}{ When should PPE be worn in COVID-19? } \\
\hline $\begin{array}{l}\text { Close contact with a patient's body fluids and } \\
\text { secretions }\end{array}$ & $434(90.6)$ \\
\hline Contact with a patient closer than 1 meter & $389(81.0)$ \\
\hline $\begin{array}{l}\text { Being in the same room with a patient for more } \\
\text { than } 15 \text { minutes }\end{array}$ & $330(68.8)$ \\
\hline Accompanying the transport of suspicious cases & $404(84.2)$ \\
\hline \multicolumn{2}{|c|}{$\begin{array}{l}\text { What should be the procedure with medical equipment to be } \\
\text { used for a COVID-19 positive patient? }\end{array}$} \\
\hline Should not be used in common & $435(90.6)$ \\
\hline Should not be taken out of the room & $413(86.0)$ \\
\hline $\begin{array}{l}\text { If it is to be taken out of the room, it must be } \\
\text { disinfected }\end{array}$ & $378(78.9)$ \\
\hline \multicolumn{2}{|l|}{ How should endotracheal intubation be performed? } \\
\hline $\begin{array}{l}\text { It should be done by educated and experienced } \\
\text { people }\end{array}$ & $352(91.4)$ \\
\hline Rapid serial intubation should be done & $299(77.5)$ \\
\hline $\begin{array}{l}\text { Positive pressure should be ventilated after the cuff } \\
\text { is inflated }\end{array}$ & $250(64.8)$ \\
\hline Closed suction system should be used & $294(76.2)$ \\
\hline $\begin{array}{l}\text { Non-invasive ventilation should be avoided when } \\
\text { secretions can't be controlled }\end{array}$ & $251(65.0)$ \\
\hline $\begin{array}{l}\text { Balloon mask ventilation should not be used if } \\
\text { possible }\end{array}$ & $193(50.0)$ \\
\hline
\end{tabular}

masks was significantly less in group CP compared to group $D(p=0.010)$, group IN ( $p=0.004)$, group SN $(p=0.001)$, and AT $(p<0.001)$. Apron/overall use was significantly lower in group CP than group D, group IN, group SN, and group AT ( $p<0.001$, $p<0.001, p=0.029, p=0.001$, respectively). The use of liquid soap was significantly lower in group AT compared to group IN ( $p=0.056$, Table 3).

Questions on endotracheal intubation were asked to the four groups except group CP (Table 4). "Should endotracheal intubation be done by educated and experienced people?" was answered correctly by group D (group SN $p<0.001$, group IN $p=0.001$ ), and group AT (group $S N p=0.001$, group IN p=0.015). "Should rapid serial intubation be performed?" was more correctly replied by group D (group SN $p<0.001$, group IN $p=0.028$ ), by group AT (group $\mathrm{SN} p<0.001$, group 
IN p=0.035), and by group IN (group SN $p<0.001$ ). Group $D$ responded correctly to the question "Should positive pressure ventilation be initiated after inflation of the cuff?" compared to the other groups (group $S N p<0.001$, group IN $p=0.001$, group AT $p=0.004)$. There was a significant difference between group $D$ and the other groups (group $S N p<0.001$, group IN $p<0.001$, and group AT $p=0.001$ ) to the question "Should a closed system aspiration system be used?". For the question "Should non-invasive ventilation be avoided in cases where secretions cannot be controlled?", group D answered significantly more correctly compared to group $S N$ and group $I N(p<0.001)$, and group $S N$ had significantly less accurate answers (group AT $p<0.001$, and group IN p=0.012). Group D and group AT gave correct answer to the question "Should balloon mask ventilation be used if possible?" compared to the other groups $(p<0.001)$.

It was observed that group IN received significantly more on-the-job training than the other groups. Among the ways of obtaining up to date information about COVID-19, social media follow-up was found to be significantly higher in group IN than in group $\mathrm{CP}(\mathrm{p}=0.012)$. Compared to group $D$, the other groups were significantly higher in obtaining information from television. In follow-up from orginal articles, group $D$ was significantly higher than the other groups $(p<0.001$, Table 5).

\section{Discussion}

To best of our knowledge, this is the first study that has thoroughly assessed the knowledge of HCWs on COVID-19, in Turkey. In our country, the first case of COVID-19 was seen on March 11, 2020, and the first death occurred on March 17, 2020. On March 21, 2020, the total number of cases was 947 and the total number of people who died was 21 . On April 5, 2020, the total number of cases was 27,069 and the number of people who lost their lives was 574. At the beginning of April, the number of patients who died daily ranged from 60 to 100 . We performed this survey during the early stage of COVID-19, 10 days after the first case was seen in Turkey. The biggest problem in the pandemic

\begin{tabular}{|l|l|l|l|l|l|l|}
\hline Table 3. Distribution of the use of personal protective equipment and disinfection material for coronavirus disease-2019 by groups \\
\hline & $\begin{array}{l}\text { Grup D } \\
\mathbf{n}(\%)\end{array}$ & $\begin{array}{l}\text { Grup IN } \\
\mathbf{n}(\%)\end{array}$ & $\begin{array}{l}\text { Grup SN } \\
\mathbf{n}(\%)\end{array}$ & $\begin{array}{l}\text { Grup AT } \\
\mathbf{n}(\%)\end{array}$ & $\begin{array}{l}\text { Grup CP } \\
\mathbf{n}(\%)\end{array}$ & $\mathbf{p}$ \\
\hline Surgical mask & $72(54.1)$ & $68(50.4)$ & $24(49.0)$ & $44(50.6)$ & $33(43.4)$ & 0.689 \\
\hline Gloves & $130(97.7)$ & $128(94.8)$ & $46(93.9)$ & $86(98.9)$ & $66(86.8)$ & 0.004 \\
\hline Face shield & $123(92.4)$ & $116(85.9)$ & $38(77.6)$ & $79(90.8)$ & $49(64.4)$ & $<0.001$ \\
\hline N95/99 mask & $122(91.7)$ & $125(92.6)$ & $48(98.0)$ & $85(97.7)$ & $60(78.9)$ & $<0.001$ \\
\hline Liquid soap & $83(62.4)$ & $91(67.4)$ & $34(69.4)$ & $43(49.4)$ & $39(51.3)$ & 0.020 \\
\hline Alcohol based hand disinfected & $106(79.7)$ & $109(80.7)$ & $42(85.7)$ & $69(79.3)$ & $52(68.4)$ & 0.154 \\
\hline 1:10 dilution sodium hypochlorite & $47(35.3)$ & $36(26.7)$ & $16(32.7)$ & $22(25.3)$ & $19(25.0)$ & 0.352 \\
\hline Apron & $125(94.0)$ & $123(91.1)$ & $41(83.7)$ & $75(86.2)$ & $50(65.8)$ & $<0.001$ \\
\hline COVID-19: Coronavirus disease-2019, D: Doctor, SN: Surgery nurse, AT: Anesthesia technician, CP: Cleaning personnel, IN: ICU nurse & & \\
\hline
\end{tabular}

Table 4. Approach for endotracheal intubation according to groups

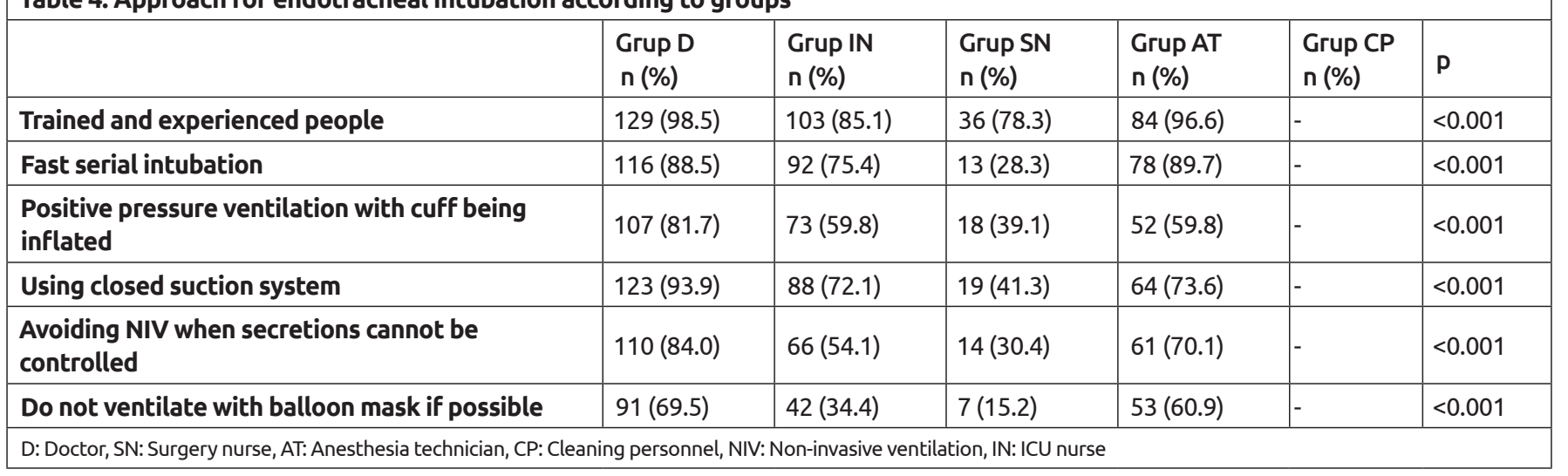




\begin{tabular}{|c|c|c|c|c|c|c|}
\hline & $\begin{array}{l}\text { Grup D } \\
\text { n (\%) }\end{array}$ & $\begin{array}{l}\text { Grup IN } \\
\text { n (\%) }\end{array}$ & $\begin{array}{l}\text { Grup SN } \\
\mathrm{n}(\%)\end{array}$ & $\begin{array}{l}\text { Grup AT } \\
\mathrm{n}(\%)\end{array}$ & $\begin{array}{l}\text { Grup CP } \\
\text { n (\%) }\end{array}$ & $P$ \\
\hline On-the-job training & $54(40.6)$ & $87(64.4)$ & $19(38.7)$ & $40(45.9)$ & $25(32.8)$ & $<0.001$ \\
\hline \multicolumn{7}{|c|}{ Obtaining information } \\
\hline Social media & $106(79.6)$ & $118(87.4)$ & $42(85.7)$ & $74(85.0)$ & $53(69.7)$ & 0.019 \\
\hline Newspaper & $26(19.5)$ & $26(19.3)$ & $10(20.4)$ & $13(14.9)$ & $11(14.4)$ & 0.782 \\
\hline Television & $82(61.6)$ & $110(81.5)$ & $43(87.7)$ & $73(83.9)$ & $67(88.1)$ & $<0.001$ \\
\hline Radio & $18(13.53)$ & $16(11.9)$ & $11(22.4)$ & $12(13.7)$ & $17(22.3)$ & 0.163 \\
\hline People around & $45(33.8)$ & $48(35.6)$ & $19(38.7)$ & $21(24.1)$ & $17(22.3)$ & 0.103 \\
\hline Orginal articles & $68(51.1)$ & $32(25.0)$ & $10(20.4)$ & $23(26.4)$ & $7(9.2)$ & $<0.001$ \\
\hline Not follow & $5(3.7)$ & $2(1.5)$ & $0(0)$ & $2(2.2)$ & $1(1.3)$ & 0.501 \\
\hline \multicolumn{7}{|l|}{ Anxiety level } \\
\hline None & $2(1.5)$ & $1(0.7)$ & $0(0)$ & $0(0)$ & $1(1.3)$ & \multirow{4}{*}{0.603} \\
\hline Mild & $31(23.3)$ & $37(27.4)$ & $10(20.4)$ & $18(20.7)$ & $21(27.6)$ & \\
\hline Moderate & $52(39.1)$ & $53(39.3)$ & $13(26.5)$ & 33 (37.9) & $26(34.2)$ & \\
\hline Severe & $48(36.1)$ & $44(32.6)$ & $26(53.1)$ & 36 (41.4) & $28(36.8)$ & \\
\hline
\end{tabular}

all over the world is that the health sector and professionals are unprepared, not having enough knowledge on the new $\mathrm{CoV}$. A high incidence of $\mathrm{CoV}$ transmission in $\mathrm{HCW}$ has been observed in the world due to the lack of personal protective equipment (PPE) and information, and some HCW cases have been fatal. $3.8 \%$ of COVID-19 cases in China are HCW (4). The late start of COVID-19 cases in Turkey has been a significant advantage for providing PPE to the health care sector compared to China and some European countries.

COVID-19 has no specific symptoms or clinical course that can be distinguished from other viral respiratory infections. In one study, 138 patients with an average age of 56 had fever (99\%), dry cough (59\%), fatigue (70\%), and nauseavomiting (10\%) (7). While the WHO has described the most common symptoms as fever, fatigue, and dry cough, other symptoms include dyspnea, muscle pain, sore throat, and diarrhea (8). In our survey, fever (96.9\%), respiratory distress $(94.2 \%)$, and cough $(92.9 \%)$ were answered as the most common symptoms, showing us that the participants had sufficient knowledge on symptoms of COVID-19.

Although the contamination time is not known exactly for COVID-19, which is transmitted from person to person, the first days of the disease are considered to be riskier in terms of contamination (9). In the report published by the WHO on February 19, it was declared that the average incubation period was 4-5 days, but extends up to 14 days
(10). In our survey, most of the participants (78\%) preferred the answer "during the first 1-2 weeks" for the contagious period of the disease. The CoV can remain alive for different periods on various surfaces in the external environment and is mainly transmitted through the mucous membrane after contact with droplets that infected people scatter on surfaces $(11,12) .68 .3 \%$ of the participants in our survey responded that the CoV survival time varies according to the environment. Although COVID-19 is seen in all age groups, it has been shown that especially older adults are more sensitive and that the severity of the disease is related to age (13). It is known that comorbidities such as hypertension, diabetes, and cardiovascular disease increase the severity of the disease, as well as the rate of fatality (14). In our survey, 61-80 years (90.6\%), presence of additional diseases (89.2\%), and being HCW (85.6\%) were stated as being at high risk for COVID-19. Our government, with quick decisions about health policy, has decided not to employ high-risk HCWs who have comorbidities. In our survey, over $68 \%$ of participants responded correctly to questions about the infectiousness of the new CoV, showing that COVID19 preparation was well planned in the early period of the pandemic in Turkey.

It is important for HCWs to quickly access accurate information throughout the pandemic. Depending on the advancement of technology, it is very easy to access 
information in our era, but the reliability of information sources is controversial. Studies reported that social media as the main source of information was used by participant HCW $(15,16)$. In our survey, $81.9 \%$ of the participants reached information on social media, while only $29.2 \%$ benefited from current orginal articles. Among the reasons for following-up less orginal articles, which are the more scientific and reliable way to access correct information, are the fact that the articles are in a foreign language.

Saqlain et al. (15) recommended that the government start well-planned training programs to increase the knowledge of all HCWs in the effective control of COVID-19. In Turkey, associations have produced online education programs and the health ministry has published a guide for COVID19. A cross-sectional another survey analyzed a total of 1,357 HCW's knowledge, practices, and attitudes regarding COVID-19. Authors' suggestion that training regarding protection from CoV should be organized according to work experience, and educational attainment. To reduce the risk of infection among $\mathrm{HCW}$, education should be implemented protection from exposure to the virus (3). Hospitals should also provide up-to-date and accurate information with on-the job training to protect HCWs from COVID-19, and standard prevention and infection control procedures should be determined, especially for high-risk units (COVID positive service, emergency service, ICU and OR, etc.). In our study, $46.9 \%$ of the respondents stated that they received on-the job training and $61.6 \%$ of the respondents stated that they have a procedure for COVID-19 in their hospitals. These rates are less than expected. It is an indication that chaos may occur with the first case of COVID-19 and therefore the risk of transmission to HCW will increase. In our survey, intensive care nurses received more on-the-job training on COVID-19 than other HCWs, but there was no difference in using PPE. However, it was determined that ICU and OR CP use PPE less than other groups. The reason why INs do not have a significant difference in questions evaluating the level of knowledge compared to other groups may be attributed to fewer years of work and experience in healthcare. It was observed that not all health workers were reached if the onthe-job training was given only once. To protect HCW from contamination in pandemics, the frequency of on-the-job training should be increased and it should provide correct information to all HCWs by updating training programs.

Since the CoV is very infectious, it is important to maintain social distance, pay attention to hand hygiene and wear a mask $(17,18)$. N95/N97 filtration masks are used in high-risk airway intervention with higher exposure to aerosol spread such as intubation, percutaneous tracheostomy, and bronchoscopy. Many organizations, including the WHO, and European Center for Disease Control report that the types of equipment should consist of N95/97 filtration masks, glasses, apron/overalls, and double gloves for COVID-19 (1921). However, $63.4 \%$ of the HCWs who participated in our survey stated that they preferred to wear a surgical mask only when they had contact with a patient. It has been determined that ICU and OR CP used PPE significantly less than other HCWs. A significant proportion of patients are asymptomatic in the perioperative period. It isn't possible to determine infection precisely because of the low sensitivity of laboratory tests and defects in sampling techniques. It is recommended to have $3 \mathrm{~min}$ preoxygenation before intubation, avoid balloon-mask positive pressure ventilation, rapid-serial intubation, and not have contact with respiratory secretions as much as possible (22). In our survey, Ds and ATs, who are more experienced in airway management, gave more appropriate answers to the recommendations of the Ministry of Health. As a result, all members of the anesthesia team fighting at the front line of COVID-19 must use PPE, especially high-risk airway interventions with higher exposure to aerosol spread (23).

Similar to other countries, in our country the anxiety associated with the uncertainty of COVID-19 is increased by the fact that the issue is handled all day in the media. "Infodemia", that is, the spread of wrong and unnecessary information besides correct information, and the high transmission and mortality rates of COVID-19, increase anxiety disorder among HCWs. In a survey conducted by Zhang et al. (3), over $85 \%$ of $1,357 \mathrm{HCW}$ were afraid of self-infection with the virus. In our study, $74.8 \%$ of the participants said that they felt moderate or severe anxiety. As HCW often regard as increased risk of infection, they often worry about family transmission, especially involving family members who are elderly, immunosuppressive, or have chronic diseases (24). We believe that HCW's anxiety levels with COVID-19 will be reduced by feeling safe while providing health care if they can easily access correct information and have no problem with the supply of PPE.

In two studies similar to our study in China and Nepal, they investigated the knowledge and attitudes of healthcare workers in the early period of COVID-19 $(3,25)$. A survey involved a total of $1,357 \mathrm{HCW}$ who comprised nurses 
$(46.5 \%)$, Ds $(36.5 \%)$, paramedics $(17.0 \%)$ (3). In the other survey, a total of 353 responses was analyzed, out of which $47 \%$ were nurses, $28.9 \%$ were Ds, $11.6 \%$ were health assistants, $2 \%$ were certified medical assistants, and the remaining $10.5 \%$ were categorized as others (pharmacists, medical lab technologists, and medical microbiologists) (25). Our survey involved a total of $480 \mathrm{HCW}$ who comprised nurses $(38.2 \%)$, Ds $(27.7 \%)$, ATs (18.1\%), and ICU and OR CP (15.8\%). In COVID-19, this study is the first to measure the knowledge level of hospital cleaning staff in the literature.

This study conducted by hand and online among HCWs during the period of the first cases reported in our country and we were unable to obtain later information from the participants. This was partly an online survey, responses mainly dependent on honesty and may have been subject to recall bias. A few number of participants and sample clustering might also limit the generalizability of the study.

\section{Conclusion}

The COVID-19 pandemic continues with unknown effects in Turkey as well as all over the world. The fact that cases started in our country later than in China and some European countries could be significant advantages that the health care capacity has not been exceeded and the relatively young age structure of our population. In order to ensure continuity in health care, HCWs who are in contact with suspect/definitive COVID-19 should use PPEs effectively, have on-the-job training programs on the pandemic at regular intervals, and be screened routinely with polymerase chain reaction tests for diagnosis of $\mathrm{CoV}$.

\section{Ethics}

Ethics Committee Approval: The study were approved by the Local Ethics Committee of the University of Health Sciences Turkey, Bursa Yüksek Ihtisas Training and Research Hospital (decision no: 2011-KAEK-25 2020/03-17, date: 18.03.2020).

Informed Consent: Informed consent forms were obtained before data collection by the researchers and were emailed to the participants of the study via the internet.

Peer-review: Externally peer-reviewed.

\section{Authorship Contributions}

Concept: C.Y., A.N.B., Design: C.Y., A.N.B., Data Collection and Process: H.E.S., S.Y., Analysis or Interpretation: F.A., S.Y., Ç.B., Literature Search: A.N.B., H.E.S., Ü.K., Ç.B., Writing: C.Y., F.A., Ü.K., Ç.B.

Conflict of Interest: No conflict of interest was declared by the authors.

Financial Disclosure: The authors declared that this study received no financial support. 


\section{References}

1. Lu R, Zhao X, Li J, Niu P, Yang B, Wu $\mathrm{H}$, et al. Genomic characterisation and epidemiology of 2019 novel coronavirus: implications for virus origins and receptor binding. Lancet 2020;395:565-74.

2. Riou J, Althaus CL. Pattern of early human-to-human transmission of Wuhan 2019 novel coronavirus (2019-nCoV), December 2019 to January 2020. Euro Surveill 2020;25:2000058.

3. Zhang M, Zhou M, Tang F, Wang $Y$, Nie $H$, Zhang $L$, et al. Knowledge, attitude, and practice regarding COVID-19 among healthcare workers in Henan, China. J Hosp Infect 2020;105:183-7.

4. Wu Z, McGoogan JM. Characteristics of and Important Lessons From the Coronavirus Disease 2019 (COVID19) Outbreak in China: Summary of a Report of 72314 Cases From the Chinese Center for Disease Control and Prevention. JAMA 2020;323:1239-42.

5. Gan WH, Lim JW, Koh D. Preventing Intra-hospital Infection and Transmission of Coronavirus Disease 2019 in Healthcare Workers. Safety and Health at Work 2020;11:241-3.

6. Storr J, Twyman A, Zingg W, Damani N, Kilpatrick C, Reilly J, et al. Core components for effective infection prevention and control programmes: new WHO evidence-based recommendations. Antimicrob Resist Infect Control 2017:6:6

7. Wang D, Hu B, Hu C, Zhu F, Liu X, Zhang $J$, et al. Clinical Characteristics of 138 Hospitalized Patients With 2019 Novel Coronavirus-Infected Pneumonia in Wuhan, China. JAMA 2020;323:1061-9.

8. WHO. Clinical management of severe acute respiratory infection when COVID19 is suspected: Interim guidance. World Health Organization 13 Mar 2020.
9. Zou L, Ruan F, Huang M, Liang L, Huang $H$, Hong $Z$, et al. SARS-CoV-2 Viral Load in Upper Respiratory Specimens of Infected Patients. N Engl J Med 2020;382:1177-9

10. WHO. Coronavirus disease (COVID-19): Situation Reports. 2020;R1-17.

11. Lam TT-Y, Shum MH-H, Zhu H-C, Tong Y-G, Ni X-B, Liao Y-S, et al. Identification of 2019-nCoV related coronaviruses in Malayan pangolins in southern China. bioRxiv 2020;1-22.

12. Wu D, Wu T, Liu Q, Yang Z. The SARSCoV-2 outbreak: What we know. Int J Infect Dis 2020;94:44-8.

13. Zhou F, Yu T, Du R, Fan G, Liu Y, Liu Z, et al. Clinical course and risk factors for mortality of adult inpatients with COVID19 in Wuhan, China: a retrospective cohort study. Lancet 2020;395:1054-62.

14. Guan WJ, Liang WH, Zhao Y, Liang HR, Chen ZS, Li YM, et al. Comorbidity and its impact on 1590 patients with COVID19 in China: a nationwide analysis. Eur Respir J 2020;55:2000547.

15. Saqlain M, Munir MM, Rehman SU, Gulzar A, Naz S, Ahmed Z, et al. Knowledge, attitude, practice and perceived barriers among healthcare workers regarding COVID-19: a crosssectional survey from Pakistan. J Hosp Infect 2020;105:419-23.

16. Depoux A, Martin S, Karafillakis E, Preet $\mathrm{R}$, Wilder-Smith $\mathrm{A}$, Larson $\mathrm{H}$. The pandemic of social media panic travels faster than the COVID-19 outbreak. J Travel Med 2020;27:31.

17. Bhagavathula AS, Aldhaleei WA, Rahmani J, Mahabadi MA, Bandari DK. Knowledge and Perceptions of COVID19 Among Health Care Workers: CrossSectional Study. JMIR Public Health Surveill 2020;6:19160.

18. Huynh G, Han Nguyen TN, Tran VK, Vo KN, Vo VT, Pham LA. Knowledge and attitude toward COVID-19 among healthcare workers at District 2 Hospital, Ho Chi Minh City. Asian Pac J Trop Med 2020;13:260-5

19. WHO. WHO Director-General's opening remarks at the mission briefing on COVID-19. 12 Mar 2020.

20. WHO. Rational use of personal protective equipment for coronavirus disease (COVID-19) and considerations during severe shortages Interim guidance 23 Dec 2020.

21. ECDC. European Center For Disease Prevention and Control. Infection Prevention and Control and Preparedness for COVID-19 in Health Care Settings -Third Update. 13 May 2020;R1-11.

22. T.C. Sağlık Bakanlığı Halk Sağlığı Genel Müdürlüğü (2020). COVID-19 (SARSCoV2 Enfeksiyonu) Rehberi (Bilim Kurulu Çalısması) 2020. p. 1-98.

23. Cook TM. Personal protective equipment during the coronavirus disease (COVID) 2019 pandemic - a narrative review. Anaesthesia 2020;75:920-7.

24. Adams JG, Walls RM. Supporting the Health Care Workforce During the COVID-19 Global Epidemic. JAMA 2020;323:1439-40

25. Nepal R, Sapkota K, Adhikari K, Paudel P, Adhikari B, Paudyal N, et al. Knowledge, attitude and practice regarding COVID-19 among health care workers in Chitwan, Nepal. Research Square 2020;1-23. 